\title{
Toxoplasma gondii in the Subarctic and Arctic
}

\author{
Kristin W Prestrud ${ }^{1 *}$, Kjetil Åsbakk', Antti Oksanen², Anu Näreaho3 ${ }^{3}$ Pikka Jokelainen ${ }^{3}$ \\ From Parasite infections of domestic animals in the Nordic countries - emerging threats and challenges. \\ The 22nd Symposium of the Nordic Committee for Veterinary Scientific Cooperation (NKVet) \\ Helsinki, Finland. 7-9 September 2008
}

\section{Summary}

The coccidian protozoan Toxoplasma gondii has a world-wide distribution. It causes toxoplasmosis, a potentially very serious disease to humans and other warm-blooded animals. Infection has in many studies been shown to be rather common in the Nordic countries also, where its prevalence both in domestic animals and wildlife can be explained by contacts with cats and their faeces, cats and wild felids being the only definitive hosts of the parasite known.

Before the discovery of the complete life cycle of the parasite, other infection routes to animals were studied e.g. in Russia, where lateral transmission of infection in a reindeer herd was reported. The vehicle of infection was apparently body fluids, such as e.g. saliva and lacrimal fluid containing parasite tachyzoites, which might invade another reindeer via mucosal membranes. According to the finding, toxoplasmosis might be apprehended to be also a sexually transmitted disease. Following the discovery of the pivotal role of the cat in the epidemiology of $T$. gondii, possible alternative pathways of infection have generally been ignored. In Fennoscandian semi-domesticated reindeer, a clear association of the seroprevalence of antibodies to T. gondii was seen with the degree of domestication, and, thus, with cat contacts [1].

In the high Arctic of Svalbard, there is a considerably high seroprevalence of infection both in polar bears and Arctic foxes [2-4]. The source of infection is unlikely to be found in the seals constituting the major part of the polar bear's diet, as in one study, antibodies were not found in North Atlantic marine mammals. However, in other, less arctic and remote, cetacean and pinniped populations studied, $T$. gondii infection has been found.

${ }^{1}$ Norwegian School of Veterinary Science, Department of Food Safety and Infection Biology, Section of Arctic Veterinary Medicine, Tromsø, Norway Full list of author information is available at the end of the article
Because Svalbard reindeer and sibling voles studied have been free from $T$. gondii infection, it can be assumed that sexual stages of infection (in definitive hosts) leading to oocyst production is not a major part of the Svalbard T. gondii life cycle [2]. Then, carnivores probably get the infection with food, anyhow. Cannibalism is considered common in polar bears and Arctic foxes, and probably can explain a lot. One parasite isolate from an Arctic fox proved to belong to the Type II strain, the predominant $T$. gondii lineage in the world [3]. This somewhat objects to the suggested idea of a specific Arctic life cycle of the parasite, but incorporates the Arctic to the global T. gondii infection network. Further support to the hypothesis is gained from the finding that Svalbard barnacle geese (Branta leucopsis) are rather commonly infected. They may get the infection when wintering in Scotland. So, perhaps migratory birds are important in $T$. gondii globalisation.

Cats are crucial to T. gondii epidemiology. However, the Arctic example proves that the successful parasite can thrive even in the absence of cats.

\section{Author details \\ ${ }^{1}$ Norwegian School of Veterinary Science, Department of Food Safety and Infection Biology, Section of Arctic Veterinary Medicine, Tromsø, Norway. ${ }^{2}$ Finnish Food safety Authority Evira, Fish and Wildlife Health Research Unit (FINPAR), Oulu, Finland. ${ }^{3}$ Department of Basic Veterinary Sciences, Faculty of Veterinary Medicine, University of Helsinki (FINPAR), Helsinki, Finland.}

Published: 13 October 2010

\section{References}

1. Oksanen A, Åsbakk K, Nieminen M, Norberg H, Näreaho A: Antibodies against Toxoplasma gondii in Fennoscandian reindeer - Association with the degree of domestication. Parasitology International 1997, 46:255-261.

2. Prestrud KW, Åsbakk K, Fuglei E, Mørk T, Stien A, Ropstad E, Tryland M, Gabrielsen GW, Lydersen C, Kovacs KM, Loonen MJ, Sagerup K, Oksanen A: Serosurvey for Toxoplasma gondii in arctic foxes and possible sources of infection in the high Arctic of Svalbard. Vet Parasitol 2007, 150:6-12. 
3. Prestrud KW, Dubey JP, Åsbakk K, Fuglei E, Su C: First isolate of Toxoplasma gondii from arctic fox (Vulpes lagopus) from Svalbard. Vet Parasitol 2008, 151:110-114.

4. Oksanen A, Åsbakk K, Prestrud KW, Aars J, Derocher A, Tryland M, Wiig Ø, Dubey JP, Sonne C, Dietz R, Andersen M, Born EW: Prevalence of antibodies against Toxoplasma gondii in polar bears (Ursus maritimus) from Svalbard and East Greenland. J Parasitol 2008, 1, [Epub ahead of print].

doi:10.1186/1751-0147-52-S1-S7

Cite this article as: Prestrud et al:: Toxoplasma gondii in the Subarctic and Arctic. Acta Veterinaria Scandinavica 2010 52(Suppl 1):S7.

Submit your next manuscript to BioMed Central and take full advantage of:

- Convenient online submission

- Thorough peer review

- No space constraints or color figure charges

- Immediate publication on acceptance

- Inclusion in PubMed, CAS, Scopus and Google Scholar

- Research which is freely available for redistribution

Submit your manuscript at www.biomedcentral.com/submit 